\title{
IDENTIFICATION OF URBAN WATER BODIES ECOSYSTEM SERVICES
}

\author{
Mateusz Jakubiak ${ }^{1 凶}$, Krzysztof Chmielowski $^{2}$ \\ ${ }^{1}$ Department of Environmental Management and Protection, Faculty of Mining Surveying and Environmental Engineering, \\ AGH University of Science and Technology in Kraków, Al. Mickiewicza 30, 30-059 Kraków, Poland \\ 2 Department of Sanitary Engineering and Water Management, Faculty of Environmental Engineering and Land Surveying, \\ University of Agriculture in Krakow, Al. Mickiewicza 21, 31-120 Kraków, Poland
}

\begin{abstract}
Aim of the study

The aim of the research is an analysis of the concept of ecosystem services in context of urban water bodies. In result of the study, final ecosystem services and the goods and benefits of urban aquatic ecosystems were identified.
\end{abstract}

\begin{abstract}
Material and methods
The study of the development of the concept of ecosystem services was based on the literature review. Water ecosystems were analyzed in terms of their ecosystem services that can be assigned to individual classes listed in CICES V5.1. The next step of the analysis was to consider which of the identified ecosystem services of water ecosystems were also provided by urban water bodies. The results of the analysis were divided into biotic and abiotic services in three basic divisions: provisioning, regulation \& maintenance, cultural services. Due to the specificity of CICES classification, examples of both, final ecosystem services and ecosystem goods and benefits, were assigned to each class code. The research was conducted in relation to Polish conditions.
\end{abstract}

\section{Results and conclusions}

The 26 biotic and 12 abiotic classes of ecosystem services provided by urban water bodies were identified in the analysis. Cultural services of the urban water bodies seem to be the most important for the daily life of city residents. The demand for urban water bodies ecosystems services grows together with increasing social awareness. Social expectations should be reflected in the decisions and actions taken by urban planners and policy makers.

Keywords: urban agglomerations, CICES, ecosystem goods and benefits

\section{INTRODUCTION}

Ecosystems in urban agglomerations are under strong human pressure and therefore are subject to significant changes. At the same time, progressive urbanization seems to be an inevitable process. Urban areas have grown rapidly in recent decades. Areas of transformed land increase with the demand for its new functions: residential, industrial and service (Das and Das, 2019). Biologically active areas decrease along with transformations of urban land. The number of inhabitants of urbanized areas is also constantly growing. In 2018, more than $55 \%$ of the world's population were city dwellers. More than $23 \%$ of people live in large agglomerations (of over a million inhabitants). United Nations estimates that these values will

凶e-mail: jakubiak@agh.edu.pl 
grow continuously (UN, 2018). Regardless of the size of the area and population, cities are complex systems with a number of simultaneous ecological and social processes (Lam and Conway, 2018). Until recently, it seemed that in rapidly developing cities urbanization processes were winning the competition for resources with the environment. However, needs and priorities of inhabitants change. New needs appear as a result of growing wealth of society. Therefore, the further development of cities, connected to resources depletion and limited buffering capacity of the biosphere, takes place in parallel with a change in thinking about the urban environment. There is also a growing public awareness of the limitations of urban ecosystem resources and the fact that they provide significant benefits to human beings (Bolund and Hunhammar, 1999; Lam and Conway, 2018). Urban ecosystems consist of two main categories, called blue and green infrastructure (Dou et al., 2017). Together with the ecological economy development, the urban ecosystems benefits provided to society began to be classified as ecosystem services (ES) (Costanza and Daly, 1992; Daily, 1997).

The aim of the undertaken analysis is to present the concept of ecosystem services of urban water bodies (UWB). The popularization of the concept results from the growing awareness of the need to preserve water ecosystems in urban spaces. In result of the study, final ecosystem services and the goods and benefits of urban aquatic ecosystems were identified. The analysis is based on the hierarchical classification CICES V5.1

\section{URBAN WATER ECOSYSTEMS}

Settlement was always associated with surface waters. Most of the cities in the world were founded either along watercourses or on the coasts of oceans, seas or lakes. Therefore, flowing and standing waters are an element of nature that used to determine the formation of human settlements. Today, waters shape the urban planning of metropolitan areas, cities, towns, rural areas, villages and even city quarters (EEA, 2016). Historically, people preferred to live near rivers and lakes because of their safety, access to water for consumption, economic and agricultural purposes. Water was a source of food and energy
(Jakubiak and Panek, 2017; Fang and Jawitz, 2019). Growing cities successively transformed fragments of surrounding ecosystems by absorbing fields, forests, meadows, wastelands or even wetlands into the urban tissue. Contemporary cities form a mosaic where the residential, industrial and communication infrastructure intertwines with ecosystems created by street trees, lawns, parks, urban forests, farmland, rivers, streams, lakes, garden ponds and wetlands. Large fragmentation of urban space often blurs the boundaries between different ecosystems. Therefore, the urban environment can be described as one urban ecosystem in which green and blue infrastructure play a key biocenotic role (Bolund and Hunhammar, 1999). However, low levels of biodiversity are characteristic for urban agglomerations (Jakubiak and Panek, 2017). The share of urban blue areas in the total urban area is much lower than in case of green areas. These parameters are a very individual feature of each city, significant differences often occur even between districts. For example, in Beijing's Fengtai district the green space accounts for $44.8 \%$ of its total area, while blue space only $0.1 \%$ (Dou et al., 2017). In Stockholm, parks and green space represent $26 \%$ and water is around $13 \%$ of the city's area. (Bolund \& Hunhammar, 1999). In Krakow, green areas account for $47 \%$ (including forests, wooded and bushy areas $-4.7 \%$ ) of the city area. The water bodies cover about $2.2 \%$ of the city's total area. (Luchter, 2009). Almost always water bodies are accompanied by green infrastructure (Szulczewska, 2018; Cieszewska, 2019). Bodies of water are especially valuable in cities, fulfilling many environmental and social functions. If urban water ecosystems are supposed to provide significant, long-term benefits to society, decision-makers must impose frameworks and restrictions on the exploitation of environments. The inventory management and protection activities, expanding the water bodies, restoring their function through revitalization or reclamation should be undertaken at the local level, by the city authorities (Wasik et al., 2017; Mazur et al., 2020). Especially the latter activities require significant financial investments, involvement of specialists, and are time consuming (Chmielowski and Ślizowski, 2008; Mazur and Sitarek, 2020). Growing environmental awareness and public expectations are increasing the demand for availability and acces- 
sibility of urban ecosystem services (Das and Das 2019). The concept of ecosystem services allows for the presentation of urban ecosystems also in terms of convertible economic values (Gómez-Baggethun and Ruiz Perez, 2011). Using ES, the need for investment in blue and green infrastructure becomes more visible, understandable and better justified for politicians and decision makers

\section{ECOSYSTEM SERVICES METHODOLOGY}

The ecosystem services, as non-market goods, are often not fully recognized. Moreover, their value is not known. The concept of ES is a two-stage approach. The first step is identification of the services provided by the ecosystem. Afterwards, it is possible to perform their financial valuation. Costanza (2020) states that the valuation should take into account the possible range of ecosystem depletion and the disturbance of their homeostasis due to economic activities. The protection and rational use of environmental resources determines long-term economic stability (Gómez-Baggethun and Ruiz Perez, 2011). Folke (2006) indicates that ES were proposed as a strategy to move away from the approach of "protection versus development" towards the vision of "protection for development". Therefore, this concept is more frequently used as an important economic tool in decision-making processes concerning the directions of public space development, undertaking protection, revitalization or other investments in areas providing ES. The use of classification and valuation of ES allows for interdisciplinary analysis - ecological and economic evaluation of anthropogenic use of the environment and its degradation (Weitzman, 2019). The ES allow to translate ecological information into familiar economic language. This approach helps to convince communities and politicians about human dependence on local components of nature. The valuation of ES makes possible the comparison of the financial and social costs of undertaken activities affecting the natural environment.

Many national and international ES classification systems were developed in recent decades. The Millennium Ecosystem Assessment (MEA), The Economics of Ecosystems and Biodiversity (TEEB) and The Common International Classification of Ecosystem Ser- vices (CICES) appear to be the three most relevant classification systems. The MEA was the first international classification. It was prepared under the auspices of the UN. This classification highlights the links between ES and quality of life (La Notte et al., 2017). The TEEB classification was supported by the European Commission and the UN Environment Programme (UNEP). In particular, it highlights the need to stress the monetary value of ES. The aim of TEEB was to make politicians and decision-makers, accustomed to using economic categories and aware of the benefits of nature conservation (Kronenberg, 2016). The CICES is a unified system, with a hierarchical structure, developed by the European Commission and the European Environment Agency (EEA). This classification was developed as part of work towards integrating the valuation of ecosystem services into accounting and reporting systems at a national level (Haines-Young and Potschin, 2018). The typology of previous classifications of ecosystem services was developed and improved during the creation of CICES. The CICES now appears to be one of the most popular classifications. It is based on the scheme of obtaining goods and ecosystem benefits from final ecosystem services by human beings. The classification defines ecosystem services as final services. The biological structure and biophysical processes are specified as supporting or intermediate services. The ecosystem contribution to human well-being takes form of final services (La Notte et al., 2017).

Water ecosystem services are strongly dependent on the climate and the geographical location as well as economic and cultural conditions of society. Therefore, the following analysis was conducted in relation to Polish conditions. The analysis was based on the cascade classification CICES V5.1 (Haines-Young and Potschin, 2018).

The analysis was performed in the following divisions: provisioning, regulation \& maintenance, cultural services. Water ecosystems were analyzed in terms of their ES that can be assigned to individual classes listed in CICES V5.1. The next step of the analysis was to consider which of the identified ES of water ecosystems were also provided by UWB. For legibility, the analysis results in tables are presented in sections, divisions and classes. Due to the specificity of CICES classification, examples of both, final 
ecosystem services and ecosystem goods and benefits, were assigned to each class code. Biotic (see: Table 1) and abiotic (see: Table 2) services are presented separately.

\section{RESULTS AND DISCUSSION}

The ecosystem services provided by surface water in cities depend on many factors. The type of water (flowing/stagnant), size of the watercourse/reservoir/ wetland and other morphometric parameters (surface, depth, water table stability), natural diversity, genesis, state of preservation, location in relation to the urbanized area (city center/districts, suburbs) are the main parameters that determine ES. These diverse characteristics of the blue infrastructure in cities create the possibility and range of ecological functions: biocenotic, physiocenotic, hydrological, biogeochemical, microclimatic as well as landscape, scientific, ed- ucational and economic (Jakubiak and Panek, 2016a; Jakubiak and Panek, 2017). Urbanization brings many challenges to the maintenance of ecosystem services. The concentration of people and housing, removal of natural land cover, increase of impermeable surfaces, waste, pollution, biogens, negatively affect UWB services. Some UWB require protective activities to prevent their disappearance. In other cases, protection is not sufficient and it is necessary to undertake investments in their maintenance, reclamation, renaturalization, restoration or even creation of completely new water reservoirs (Jakubiak and Panek, 2016b; Mazurkiewicz et al., 2020; Sitarek et al., 2017). Additionally, it should be taken into account that Poland is experiencing water shortages (Kopacz et al. 2018). Negligence in regard to rational water management, including small retention, will deprive the society of many benefits provided by UWB.

Table 1. Biotic ecosystem services of urban water bodies (based on CICES V5.1)

\begin{tabular}{|c|c|c|c|c|}
\hline Section & Division & $\begin{array}{l}\text { Class } \\
\text { Code }\end{array}$ & Ecosystem services & Ecosystem goods and benefits \\
\hline \multirow[t]{7}{*}{ Provisioning } & Biomass & 1.1.2.1 & $\begin{array}{l}\text { Volume of harvested medicinal } \\
\text { plants }\end{array}$ & $\begin{array}{l}\text { Herbal supplements e.g. sweet } \\
\text { flag (Acorus calamus L.) }\end{array}$ \\
\hline & & 1.1.2.3 & Volume of harvested willow wood & Fuel wood \\
\hline & & 1.1.4.1 & Harvestable stock of fish & $\begin{array}{l}\text { Fish from aquaculture (e.g. trout, } \\
\text { carp, sturgeon) }\end{array}$ \\
\hline & & 1.1.4.2 & $\begin{array}{l}\text { Harvestable volume of reeds, willow } \\
\text { or aquatic plants }\end{array}$ & $\begin{array}{l}\text { Material for making baskets and } \\
\text { other handicrafts, aquatic plants } \\
\text { used for compost production }\end{array}$ \\
\hline & & 1.1.5.1 & $\begin{array}{l}\text { Macrophytes harvested in the } \\
\text { shallow sublittoral and/or littoral } \\
\text { zone e.g. broadleaf cattail } \\
\text { (Typha latifolia L.), Water caltrop } \\
\text { (Trapa natans L.) }\end{array}$ & $\begin{array}{l}\text { Food products, e.g. meal made } \\
\text { of broadleaf cattail } \\
\text { (Typha latifolia L.) rhizome }\end{array}$ \\
\hline & & 1.1.5.3 & Volume of harvested wood or grass & Fuel wood (willow, reed) \\
\hline & $\begin{array}{l}\text { Genetic material from } \\
\text { all biota }\end{array}$ & 1.2.1.1 & Seeds that can be harvest & $\begin{array}{l}\text { Wild plant seeds and other } \\
\text { plant materials collected for } \\
\text { maintaining a population }\end{array}$ \\
\hline
\end{tabular}


Jakubiak, M., Chmielowski, K. (2020). Identification of urban water bodies ecosystem services. Acta Sci. Pol., Formatio Circumiectus, 19 (3), 73-82. DOI: http://dx.doi.org/10.15576/ASP.FC/2020.19.3.73

Table 1. cd.

\begin{tabular}{|c|c|c|c|c|}
\hline Section & Division & $\begin{array}{l}\text { Class } \\
\text { Code }\end{array}$ & Ecosystem services & Ecosystem goods and benefits \\
\hline \multirow[t]{9}{*}{$\begin{array}{l}\text { Regulation \& } \\
\text { Maintenance }\end{array}$} & $\begin{array}{l}\text { Transformation } \\
\text { of biochemical or } \\
\text { physical inputs to } \\
\text { ecosystems }\end{array}$ & 2.1.1.1 & $\begin{array}{l}\text { The bioextraction, biodegradation, } \\
\text { rhizospheric biodegradation capacity } \\
\text { of water microorganisms, algae, } \\
\text { plants, and animals }\end{array}$ & $\begin{array}{l}\text { Wetlands as last stage of } \\
\text { wastewater treatment. }\end{array}$ \\
\hline & & 2.1.1.2 & $\begin{array}{l}\text { The biomagnification or } \\
\text { bioaccumulation capacity of } \\
\text { microorganisms, algae, plants, and } \\
\text { animals }\end{array}$ & Wastewater purification \\
\hline & $\begin{array}{l}\text { Regulation of physical, } \\
\text { chemical, biological } \\
\text { conditions }\end{array}$ & 2.2.1.3 & $\begin{array}{l}\text { The capacity to retain water and } \\
\text { release it slowly, flood prevention, } \\
\text { small retention }\end{array}$ & $\begin{array}{l}\text { Mitigation of flood/storm events } \\
\text { damages }\end{array}$ \\
\hline & & 2.2.1.5 & $\begin{array}{l}\text { The capacity of wetlands, ponds } \\
\text { or watercourses to reduce the } \\
\text { frequency, spread or magnitudes of } \\
\text { fires. }\end{array}$ & Reduction of fire damages \\
\hline & & 2.2.2.2 & $\begin{array}{l}\text { Hydrochory (wild plants seeds } \\
\text { dispersal by water) }\end{array}$ & $\begin{array}{l}\text { Dispersal of seeds and plant } \\
\text { seedlings with the current of the } \\
\text { river }\end{array}$ \\
\hline & & 2.2.2.3 & $\begin{array}{l}\text { Important nursery habitats include } \\
\text { wetlands, littoral zones, or small } \\
\text { water bodies. Emergent zones } \\
\text { in water bodies as the habitat of } \\
\text { juvenile fish and other aquatic } \\
\text { animals. }\end{array}$ & $\begin{array}{l}\text { Maintaining populations } \\
\text { important to other ecosystems, } \\
\text { e.g. amphibians }\end{array}$ \\
\hline & & 2.2.5.1 & $\begin{array}{l}\text { Self-purification capacity, removing } \\
\text { nutrients }\end{array}$ & $\begin{array}{l}\text { Neutralization of pollutions, } \\
\text { e.g. nutrient runoff from } \\
\text { agroecosystems }\end{array}$ \\
\hline & & 2.2.6.1 & $\begin{array}{l}\text { Lakes/reservoirs/wetlands as } \\
\text { regulators of carbon cycle }\end{array}$ & $\begin{array}{l}\text { Climate regulation (resulting in } \\
\text { avoided damage costs) }\end{array}$ \\
\hline & & 2.2.6.2 & $\begin{array}{l}\text { Mitigating heat island effects and } \\
\text { increasing humidity in cities }\end{array}$ & $\begin{array}{l}\text { Regulation of thermal comfort in } \\
\text { urban agglomerations }\end{array}$ \\
\hline \multirow[t]{2}{*}{ Cultural } & $\begin{array}{l}\text { Direct, in-situ and } \\
\text { outdoor interactions } \\
\text { with living systems } \\
\text { that depend on } \\
\text { presence in the }\end{array}$ & 3.1.1.1 & $\begin{array}{l}\text { Ecological qualities of watercourses/ } \\
\text { lakes/wetland/garden ponds that } \\
\text { make areas more attractive to } \\
\text { walking; opportunities for diving or } \\
\text { swimming }\end{array}$ & $\begin{array}{l}\text { Nature-based sport, fitness, } \\
\text { recreation, de-stressing or mental } \\
\text { health }\end{array}$ \\
\hline & & 3.1 .1 .2 & $\begin{array}{l}\text { Species in watercourses/lakes/ } \\
\text { wetlands that interest birdwatchers; } \\
\text { animals or plants that can be } \\
\text { enjoyed by wildlife watchers }\end{array}$ & $\begin{array}{l}\text { Nature-based sport, fitness, } \\
\text { recreation, de-stressing or mental } \\
\text { health }\end{array}$ \\
\hline
\end{tabular}


Table 1. cd.

\begin{tabular}{|c|c|c|c|c|}
\hline Section & Division & $\begin{array}{l}\text { Class } \\
\text { Code }\end{array}$ & Ecosystem services & Ecosystem goods and benefits \\
\hline & & 3.1.2.1 & Areas of special scientific interest & $\begin{array}{l}\text { Knowledge about the environment } \\
\text { and nature e.g. habitat or } \\
\text { reproduction conditions of rare } \\
\text { species }\end{array}$ \\
\hline & & 3.1.2.2 & $\begin{array}{l}\text { Areas used for voluntary } \\
\text { conservation activities or outdoor } \\
\text { lessons }\end{array}$ & $\begin{array}{l}\text { Environment management } \\
\text { practice and knowledge }\end{array}$ \\
\hline & & 3.1.2.3 & $\begin{array}{l}\text { Local watercourses/lakes/wetland } \\
\text { being an element of the cultural } \\
\text { heritage of the city (e.g. legends), } \\
\text { places of cultural event (e.g. Lake } \\
\text { Malta in Poznań) }\end{array}$ & Local identity, tourist attractions \\
\hline & & 3.1.2.4 & $\begin{array}{l}\text { Areas of outstanding natural beauty } \\
\text { values; viewpoints }\end{array}$ & $\begin{array}{l}\text { Painting, poetic and other artistic } \\
\text { inspiration }\end{array}$ \\
\hline & \multirow{4}{*}{$\begin{array}{l}\text { Indirect, remote, often } \\
\text { indoor interactions } \\
\text { with living systems } \\
\text { that do not require } \\
\text { presence in the } \\
\text { environmental setting }\end{array}$} & 3.2.1.1 & $\begin{array}{l}\text { Habitats, animals or plants with } \\
\text { significance symbolic, cultural or } \\
\text { historical character (e.g. stork, Oak } \\
\text { Bartek) }\end{array}$ & $\begin{array}{l}\text { Social cohesion, cultural } \\
\text { identification }\end{array}$ \\
\hline & & 3.2 .1 .3 & $\begin{array}{l}\text { Scenery for movies or photos } \\
\text { (e.g. wedding photo sessions) }\end{array}$ & Photos and films \\
\hline & & 3.2 .2 .1 & $\begin{array}{l}\text { Parts of watercourses/lakes/wetland } \\
\text { designated as wilderness }\end{array}$ & Mental or moral well-being \\
\hline & & 3.2 .2 .2 & $\begin{array}{l}\text { Endangered water habitats or } \\
\text { species }\end{array}$ & Mental or moral well-being \\
\hline
\end{tabular}

Table 2. Abiotic ecosystem services of urban water bodies (based on CICES V5.1)

\begin{tabular}{ccccc}
\hline Section & Division & $\begin{array}{r}\text { Class } \\
\text { Code }\end{array}$ & \multicolumn{1}{c}{ Ecosystem services } & Ecosystem goods and benefits \\
\hline Provisioning & Water & 4.2 .1 .1 & $\begin{array}{l}\text { Fresh water from a natural springs; } \\
\text { volume and characteristics of water } \\
\text { from reservoirs and rivers enabling } \\
\text { its use for water supply system }\end{array}$ & Potable water in supply system \\
\cline { 3 - 5 } & 4.2 .1 .2 & $\begin{array}{l}\text { Volume and characteristics of water } \\
\text { enabling its use for irrigation or } \\
\text { industry }\end{array}$ & $\begin{array}{l}\text { Reduced energy costs; glass } \\
\text { house cultivation }\end{array}$ \\
\cline { 3 - 5 } & 4.2 .1 .3 & Hydraulic potential of watercourses & $\begin{array}{l}\text { Energy produced by hydropower } \\
\text { plants }\end{array}$ \\
\hline
\end{tabular}


Table 2. cd.

\begin{tabular}{|c|c|c|c|c|}
\hline \multirow[t]{5}{*}{$\begin{array}{l}\text { Regulation \& } \\
\text { Maintenance }\end{array}$} & \multirow{3}{*}{$\begin{array}{l}\text { Transformation } \\
\text { of biochemical or } \\
\text { physical inputs to } \\
\text { ecosystems }\end{array}$} & 5.1 .1 .1 & $\begin{array}{l}\text { Use of watercourses/lakes/wetland } \\
\text { as a pollution sink }\end{array}$ & $\begin{array}{l}\text { Dilution of mine water, treated } \\
\text { sewage in watercourses }\end{array}$ \\
\hline & & 5.1 .1 .3 & $\begin{array}{l}\text { Physicochemical removal of toxins } \\
\text { (filtration, sequestration, storage or } \\
\text { accumulation) }\end{array}$ & $\begin{array}{l}\text { Geochemical effects of bottom } \\
\text { sedimentation of reservoirs or } \\
\text { wetlands }\end{array}$ \\
\hline & & 5.1.2.1 & $\begin{array}{l}\text { Garden and parks ponds, cascade, } \\
\text { fountains }\end{array}$ & Visual quality \\
\hline & \multirow{2}{*}{$\begin{array}{l}\text { Regulation of physical, } \\
\text { chemical, biological } \\
\text { conditions }\end{array}$} & 5.2 .1 .2 & Small retention & $\begin{array}{l}\text { Reduction in damage costs of } \\
\text { floods }\end{array}$ \\
\hline & & 5.2 .2 .1 & $\begin{array}{l}\text { Breeze (e.g. reservoir with } \\
\text { a fountain) }\end{array}$ & $\begin{array}{l}\text { Human comfort in parks and } \\
\text { other urban areas }\end{array}$ \\
\hline \multirow[t]{4}{*}{ Cultural } & \multirow{2}{*}{$\begin{array}{l}\text { Direct, in-situ and } \\
\text { outdoor interactions } \\
\text { with natural physical } \\
\text { systems that depend } \\
\text { on presence in the } \\
\text { environmental setting }\end{array}$} & 6.1.1.1 & $\begin{array}{l}\text { River valleys, basins of water } \\
\text { reservoirs e.g. water reservoir in } \\
\text { a closed quarry }\end{array}$ & Ecotourism \\
\hline & & 6.1 .2 .1 & $\begin{array}{l}\text { Thought-provoking watercourses/ } \\
\text { lakes/wetlands }\end{array}$ & Recreation \\
\hline & \multirow{2}{*}{$\begin{array}{l}\text { Indirect, remote, often } \\
\text { indoor interactions } \\
\text { with physical systems } \\
\text { that do not require } \\
\text { presence in the } \\
\text { environmental setting }\end{array}$} & 6.2 .1 .1 & $\begin{array}{l}\text { Local watercourses/lakes/wetland, } \\
\text { which are important as symbols e.g. } \\
\text { the Vistula River }\end{array}$ & Local Identity \\
\hline & & 6.2 .2 .1 & $\begin{array}{l}\text { Local watercourses/lakes/wetland, } \\
\text { which are important to society and } \\
\text { future generations }\end{array}$ & Cultural meaning \\
\hline
\end{tabular}

Each urban water ecosystem can generate simultaneously many of the ES listed in the analysis (see: Table 1, Table 2). While the value of individual services may be small, the total value of all services is potentially significant. The CICES V5.1 classification includes 58 biotic and 30 abiotic ES classes. However, ES provided by water bodies do not represent all classes. In addition, the specificity of urban surface water bodies further limits the number of performed ES. The analysis identified 26 biotic and 12 abiotic ES classes provided by urban water bodies. Many specific ES can be assigned to each class. Based on the analysis, it can be concluded that the provisioning services in urban ecosystems are quite limited. An important role is played by the water supply of the municipal water supply system or industry. However, the supply of biomass for nutritional, energy or in- dustrial purposes is not the domain of urban waters. Rather, these are the ES characteristic for waters in suburbs or agricultural areas (e.g. aquaculture). The regulation $\&$ maintenance services are quite strongly represented in urban ecosystems. Small water retention and purification of pollutants and biogens are important services provided by shallow waters, small bodies of water and also by wetlands, which sometimes are present in less urbanized parts of the city. Water in parks or in between dense residential development affects the microclimate, reduces the effect of urban heat island and increases air humidity. The cultural services are most appreciated by residents in their daily lives. Providing opportunities for sports, recreation, leisure, nature education, artistic inspiration or cultural identification is particularly highly esteemed by city dwellers. 
Undoubtedly, locally generated urban ES have a direct impact on the quality of life of residents. This influence is more often noticed and appreciated. The residents perceive urban blue areas as having higher value than urban green areas. Residents indicated that they prefer to use and appreciate more the functions of urban rivers, lakes and wetlands (they take dogs for walks or take short family trips, organize picnics by the rivers or lakes, fish, take photos, create paintings or drawings, do sports, rest) (Dou et al., 2017). Therefore, city dwellers more often are willing to accept additional costs to be able to live in the immediate vicinity of green areas, especially if water bodies are available as well (Bolund and Hunhammar, 1999). Moreover, an increasing percentage of the population is willing to participate in the costs of protecting urban ecosystems in order to be able to use them (Dou et al., 2017).

\section{CONCLUSIONS}

The financial valuation of the ecosystem services provided by an assessed element of the blue infrastructure must be preceded by an identification of ES. Individual water ecosystems in a city generate simultaneously many biotic and abiotic ES, which can be classified in terms of provisioning, regulation \& maintenance and cultural services. In the conducted analysis, the ecosystem services of urban surface waters were assigned to 38 classes. Cultural services are especially important for city dwellers. Regulation \& maintenance services are come second. Supply services in case of UWB, apart from water supply, seem to be marginal.

Growing public awareness of water ecosystem services can contribute to more rational planning of urban development. The social demand for urban water ecosystems services and the possibility of their valuation should be reflected in the actions taken by urban planners and policy makers.

\section{REFERENCES}

Folke C. (2006). The economic perspective: Conservation against development versus conservation for development, Conservation Biology 20, 686-688. DOI: org/10.1111/j.1523-1739.2006.00446.x
Cieszewska A. (2019). Green belts - zielone pierścienie wielkich miast. Warszawa: Wydawnictwo Akademickie Sedno.

Chmielowski K., Ślizowski R. (2008). Effect of grain-size distribution of sand on the filtrate quality in vertical-flow filters. Przemysł Chemiczny 87(5), 432-434.

Costanza, R., Daly, H. E. (1992). Natural Capital and Sustainable Development, Conservation Biology 6(1), 37-46. DOI: org/10.1046/j.1523-1739.1992.610037.x

Costanza R. (2020). Ecological economics in 2049: Getting beyond the argument culture to the world we all want, Ecological Economics 168. DOI: doi.org/10.1016/j. ecolecon.2019.106484

Daily, G. C. (1997). (ed.) Nature's services: societal dependence on natural ecosystems, Washington, DC: Island Press, 392.

Das, M., Das, A. (2019). Dynamics of Urbanization and its impact on Urban Ecosystem Services (UESs).: A study of a medium size town of West Bengal, Eastern India Journal of Urban Management, 8(3), 420-434. doi. org/10.1016/j.jum.2019.03.002

Dou, Y., Zhen, L., De Groot, R , Du, B., Yu, X. (2017). Assessing the importance of cultural ecosystem services in urban areas of Beijing municipality. Ecosystem Services, 24, 79-90. DOI: org/10.1016/j.ecoser.2017.02.011

Fang, Y. Jawitz, J.W. (2019). The evolution of human population distance to water in the USA from 1790 to 2010. Nature Communications, 10(430). DOI:10.1038/ s41467-019-08366-z

Folke C. (2006). The economic perspective: Conservation against development versus conservation for development, Conservation Biology 20(3), 686-688. DOI: org/10.1111/j.1523-1739.2006.00446.x

Gómez-Baggethun, E., Ruiz Perez, M. (2011). Economic valuation and the commodification of ecosystem services. Progress in Physical Geography, 35(5), 613-628. DOI: org/10.1177/0309133311421708

Haines-Young, R. and M.B. Potschin (2018) Common International Classification of Ecosystem Services (CICES) V5.1 and Guidance on the Application of the Revised Structure.

Jakubiak, M., Panek, E. (2016a). Methodology of surveying small bodies of water in urban areas. Geoinformatica Polonica, 15, 135-142. DOI: 10.4467/21995923GP.16.022.5723

Jakubiak, M., Panek, E. (2016b). Small Water Bodies in the Valley of the River Rudawa in Krakow - the Environmental Value. Geomatics and Environmental Engineering 10(1), 45-57. DOI: doi.org/10.7494/geom.2016.10.1.45

Jakubiak, M., Panek, E. (2017). Małe zbiorniki wodne w zachodniej części Krakowa. Wydawnictwa AGH: Kraków. 
Jakubiak, M., Urbański, K. (2016). Urban planning solutions in the context of dispersion of road pollution. Journal of Water and Land Development, 30, 71-80. DOI: 10.1515/jwld-2016-0023

Kopacz, M., Twardy, S. (2011). The land use changes in agricultural areas between 1980 and 2005 with particular emphasis on permanent grasslands - an example of the upper Raba River basin. Journal of Water and Land Development, 15, 19-28. DOI: 10.2478/v10025-012-0002-3

Kopacz, M., Kowalczyk, A., Smoroń, S., Ostrach, Z. (2018). Sustainable management of water resources in terms of the water needs for agricultural purposes in small rural communes based on the example of the Grybów commune, Poland. Journal of Water and Land Development, 39, 67-76. DOI: 10.2478/jwld-2018-0060

Kronenberg J. (2016) Usługi ekosystemów - nowe spojrzenie na wartość środowiska przyrodniczego, In: A. Rzeńca (ed.)., EkoMiasto\#Środowisko. Zrównoważony, inteligentny i partycypacyjny rozwój miasta, Łódź: Wydawnictwo Uniwersytetu Łódzkiego, 63-88.

La Notte, A., D’Amato, D., Mäkinen, H., Paracchini, M. L., Liquete, C., Egoh, B., Geneletti, D., Crossman, N.D. (2017). Ecosystem services classification: A systems ecology perspective of the cascade framework, Ecological Indicators 74, 392-402. DOI: org/10.1016/j.ecolind.2016.11.030

La Notte, A., Vallecillo, S, Marques, A., Maes, J. (2019). Beyond the economic boundaries to account for ecosystem services Ecosystem Services, 35, 116-129. DOI: org/10.1016/j.ecoser.2018.12.007

Lam, S. T., Conway, T. M. (2018). Ecosystem services in urban land use planning policies: A case study of Ontario municipalities. Land Use Policy, 77, 641-651. DOI: org/10.1016/j.landusepol.2018.06.020

Luchter, L. (2009).Tendencje zmian użytkowania ziemi w Krakowie w latach 1848-2008 Świat Nieruchomości, 1(67), 30-37.

Mazur, A., Wagner, A., Mazur, R., Bedla, D. (2020). Bioremediacja mikrobiologiczna zdegradowanych wód jako alternatywa dla metod chemicznego oczyszczania zbiorników. Przemysl Chemiczny, 99(9), 1344-1347. DOI: 10.15199/62.2020.9.18

Mazur, R., Sitarek, M. (2020). Microbiological bioremediation of the Kamienna Góra dam reservoir. Acta Scientiarum Polonorum Formatio Circumiectus 19(1), 47-59. DOI: org/10.15576/ASP.FC/2020.19.1.47

Mazurkiewicz, J., Mazur, A., Mazur R., Chmielowski K., Czekała W., Janczak D. (2020) The Process of Microbiological Remediation of the Polluted Słoneczko Reservoir in Poland: For Reduction of Water Pollution and Nutrients Management. Water, 12, 3002, DOI: org/10.3390/w12113002

Potschin, M., Haines-Young, R. (2011). Ecosystem services: Exploring a geographical perspective. Progress in Physical Geography, 35(5), 575-594. DOI: org/10.1177/ 0309133311423172

Sitarek, M., Napiórkowska-Krzebietke, A., Mazur, R., Czarnecki, B., Pyka J.P., Stawecki, K., Olech, M., Sołtysiak, S., Kapusta, A. (2017). Application of Effective Microorganisms technology as a lake restoration tool - a case study of Muchawka Reservoir. Journal of Elementology. 22(2), 529-543. DOI: 10.5601/jelem.2016.21.2.1196

Szulczewska B. (2018). Zielona infrastruktura - czy koniec historii? KPZK PAN, Studia 189, Warszawa.

United Nations (2019). World Urbanization Prospects 2018. The World's Cities in 2018. UN Department of Economic and Social Affairs.

Wąsik E., Bugajski P., Chmielowski K., Nowak A., Mazur R., (2017). Crystallization of struvite and hydroxyapatite during removal of biogenic compounds on the filter bed, In: Przemysł Chemiczny, 96(8), 1739-1743, DOI:10.15199/62.2017.8.27

Weitzman J., (2019). Applying the ecosystem services concept to aquaculture: A review of approaches, definitions, and uses. Ecosystem Services, 35, 194-206. DOI: org/ 10.1016/j.ecoser.2018.12.009

\section{IDENTYFIKACJA USŁUG EKOSYSTEMOWYCH MIEJSKICH ZBIORNIKÓW WODNYCH}

\section{ABSTRAKT}

\section{Cel badania}

Celem badań jest analiza koncepcji usług ekosystemów w kontekście miejskich zbiorników wodnych. Wynikiem badań jest zaprezentowana identyfikacja końcowych usług oraz dóbr i korzyści płynących z miejskich ekosystemów wodnych. 


\section{Materiały i metody}

Analiza rozwoju koncepcji usług ekosystemowych została oparta na przeglądzie literatury. Ekosystemy wodne analizowano pod kątem ich usług, które można przypisać do poszczególnych klas wymienionych w CICES V5.1. Kolejnym etapem było rozważenie, które ze zidentyfikowanych usług są świadczone również w przestrzeni miejskiej przez ekosystemy wodne. Wyniki analizy zostały podzielone na usługi biotyczne i abiotyczne w trzech podstawowych działach usług: zaopatrzenia, regulacji i utrzymania oraz kulturowych. Ze względu na specyfikę klasyfikacji CICES, do każdego kodu klasy przypisano przykłady zarówno końcowych usług ekosystemów, jak i dóbr i korzyści ekosystemów. Analiza została przeprowadzona z uwzględnieniem polskich uwarunkowań.

\section{Wyniki i wnioski}

Przeprowadzona analiza pozwoliła na identyfikacje 26 klas biotycznych i 12 klas abiotycznych usług ekosystemów świadczonych przez miejskie wody powierzchniowe. Zidentyfikowane usługi kulturowe wydają się mieć największe znaczenie dla codziennego życia mieszkańców miast. Zapotrzebowanie na usługi miejskich ekosystemów wodnych rośnie wraz z rozwojem świadomości społecznej. Oczekiwania wyrażane przez społeczeństwo powinny znaleźć odzwierciedlenie w decyzjach i działaniach podejmowanych przez urbanistów i decydentów politycznych.

Słowa kluczowe: aglomeracje miejskie, CICES, dobra i korzyści ekosystemowe 